\title{
Dekonstruksi Epistemologi Muhammad Shahrur
}

\author{
Suheri Sahputra Rangkuti \\ suberiray@gmail.com
}

\begin{abstract}
Abstrak
Cara pandang masa lalu mengeluarkan kebijakan fiqh sangat dipengaruhi episteme (dalam bahasa Arkoun) di masanya. Tentu hal ini tidak menjadi titik permasalahannya saat ini. Masalah utamanya adalah menarik bangunan berpikir masa lalu, baik ia dalam ranah epistemologi maupun dalam tataran aksiologi. Akhirnya, banyak fiqh yang hanya sekedar membengkak dan upaya rasionalisasi konstruk masa klasik tanpa membongkar dan membangun ulang dari awal. Kebijakan fiqh yang seperti ini pasti berbenturan dengan masa kini, sebut saja misalnya fiqh tentang wanita yang banyak menutup ruang gerak mereka, karena episteme klasik yang maskulin dan patriarkis membuat kehilangan kemerdekaan mereka bahkan dianggap tidak pantas walau hanya sekedar menentukan arah hidupnya. Shahrur datang dengan pembacaan dan Dekonstruksi epistemologi dalam fiqh wanita sehingga menghasilkan fiqh yang ramah dalam nuansa kekinian. Meski cara yang ia tempuh tergolong tidak mainstream tetapi mega proyek yang ia tangani layak untuk diteliti dan diperbincangkan.
\end{abstract}

Kata kunci: Fiqh, Episteme, Muhammad Shahrur

\begin{abstract}
Abstrac
The past viewpoint of issuing fiqh policy was strongly influenced by episteme (in Arkoun) in his time. Of course this is not the point of the problem at this time.The main problem is to draw the building of past thinking, both in the epistemological realm and in the axiology level. Finally, many fiqh are merely swell and attempts to rationalize the classical mass construct without dismantling and rebuilding from scratch. This fiqh policy must inevitably clash with the present, for example, fiqh about women, which closes a lot of their space, because classical masculine and patriarchal epistemes make them lose their independence even considered inappropriate even if they only determine the direction of their lives. Shahrur came by reading and deconstructing the epistemology in women's fiqh so as to produce friendly figh in the present nuance. Although the way he traveled was classified as not mainstream, the mega project he handled was worthy of investigation and discussion.
\end{abstract}

Keyword: Fiqh, Episteme, Muhammad Shahrur

Al Istinbath : Jurnal Hukum Islam vol. 3, no. 2, 2018

IAIN Curup-Bengkulu | p-issn: 2548-3374; e-issn: 2548-3382

Available online at : http://journal.staincurup.ac.id/index.php/alistinbath 


\section{Pendahuluan}

Kemandekan umat Islam saat ini sering menjadi sorotan para pemikir, baik ia dikalangan non muslim (orientalis) maupun dalam internal umat Islam sendiri. Berbagai cara dilakukan dalam melacak akar masalahmangkraknya mega proyek kitab suci (Al-Qur`an) yang sudah pernah terrealisasikan pada masa lalu (bahkan sudah membuat umat Islam pada puncak kejayaannya), dari meneliti kembali produk Turast dengan memilah dan merekayasa ulang teori yang sudah ada pada masa lampau hingga titik yang paling ekstrim sekalipun, yaitu, merekonstruksi epistemologi dengan pendekatan dan teori baru, guna menghasilkan produk yang diupayakan ramah dengan realitas kekinian.Meski para pemikir menggunakan metodologi yang variatif, namun pada umumnya, para pemikir terlihat satu pandangan bahwa mandeknya umat Islam menurut diagnosa yang mereka lakukanadalah dikarenakanumat Islam hanya mengkonsumsi produk masa lalu yang sarat dengan bau politik dan kepentingan tanpa mengadakan pembacaan ulang. Meski demikian, umat Islam tidak berhak menjadikan masa lalu sebagai alasan menurunnya kualitas umat Islam saat ini. Justru kesalahan itu terletak di tangan umat Islam sekarang disebabkan masih berpegang teguh dan mengunyah mentah-mentah hasil pemikiran klasik yang sudah barang tentu banyak yang tidak kondusif dengan realitas yang ada saat ini. Ditambah lagi diskusi-diskusi syariah yang banyak diminati hanya sekedar memilih dan memilah pendapat para ulama fiqh terdahulu yang pada umumnya beredar pada logika deduktif.

Salah satu pemikir muslim yang namanya sering diperbincangkan dan kontroversial adalah Muhammad Shahrur. Ia diperbincangkan di kalangan pemikir muslim, bukan hanya karena teori baru yang ia munculkan, juga bacground-nya yang bukan dari kultur Islamic Studies menambah list nama para pemikir muslim yang menolak dan mendukung pemikirannya. Di lain pihak ada juga yang skeptis terhadap metodologi Shahrur apakah bisa berjalan seimbang dengan tatanan Iman, Islam dan Ihsan yang berjalan secara berdampingan. Terlepas dari pro dan kontra itu, Shahrur ternyata memberikan pembacaan baru yang lumayan mengesankan dan tidak kalah dibanding pemikir lain. Dalam kitab "Nab\}wa Usul Jadidah lil Fiqh al-Islami (Fiqh al-Mar'ah)" Muhammad Shahrur mengemukakan ada titik masalah yang membuat terjadinya gesekan antara buah pemikiran dalam ranah figh dengan kondisi sosial saat ini, yaitu perangkap sejarah dalam turast yang penuh bias politik sehingga tidak relevan lagi dalam menentukan pola keberagaman perempuan sekarang ini, yang menurutnya, perlu dibongkar ulang lalu membaca langsung dari Qur'an guna melihat petunjuk murni sebelum terkontaminasi dengan segala pengaruh lokal dan temporal. Ditambah lagi dengan unsur maskulinitas dalam gawang epistemologi yang sejak 
dulu lebih banyak diperankan oleh laki-laki. Parahnya, kebijakan fiqh turast dijadikan sebagai dasar berpikir fiqh masa kini, bahkan fiqh saat ini kebanyakan hanya rasionalisasi fiqh turast terhadap realiatas tanpa menggunakan pembacaan baru. ${ }^{1}$

Melihat sangat kentalnya hubungan konteks masa lalu dengan formula dan hasil fiqh saat ini memberikan kesenjangan yang merembet kepada terpenjaranya para kaum hawa. Yang semestinya, para kaum hawa juga berhak tampil berperan dalam ruang publik, di samping itu juga berbagai kebijakan fiqh masa lalu yang tidak mempertimbangkan hak-hak wanita menjadikan kaum hawa tidak memiliki otoritas dalam hidupnya, selain dikendalikan dan dipegang oleh kaum laki-laki. Dalam tataran ini Muhammad Shahrur merekonstruksi epistemologi ulang fiqh wanita dengan mengajukan hipotesis awal, bahwa nilainilai moral tidak bisa dipisahkan baik dengan negara maupun masyarakat. ${ }^{2}$ Dengan begitu, dekonstruksi epistemologi fiqh menjadi sebuah hal yang penting guna membangun kembali semangat Qur'an yang egalitarian. Makalah ini hanya memperlihatkan upaya dekonstrusksiyang ditawarkan oleh MuhammadSharur, guna melihat sisi penting dari epistemologi hukum Islam menurut versinya. proyekyang telah lama di nanti ini sangat berkonstribusi dalam spektrum yang menghidupkan kembali otoritas perempuan baik dalam individunya maupun ditengah-tengah masyarakat dan negara.

\section{Pembahasan}

\section{Landasan Filosofis Shahrur}

Dalam pembacaannya dimulai dari mengamati bahwa seluruh ciptaan Tuhan tidak terlepas dari tiga hal, ia mengatakan,

Tiang penyanggah dari kajian filosofis tidak lari dari tiga area pembahasan yaitu, Ilahiah (teologis), Tabi'iyah (naturalistik), Insaniyah (antropologis). Merujuk kepada fakta, bahwa sesuatu itu dimulai dari ada (كينون), kemudian berproses (السيروة) adalah gerak perjalanan masa, kemudian berubah menjadi (الصيورة) adalah akhir dari bentuk yang ada (كيونة) yang pertama setelah melewati tahapan proses. ${ }^{3}$

Lahan pembacaan filosofis ini dibuat oleh Shahrur untuk membaca segala realitas seluruh ciptaan Tuhan, termasuk segala perangkat yang saling

\footnotetext{
${ }^{1}$ Moh. Shofan, Jalan Ketiga Pemikiran Islam, Cet. I. (Jogjakarta: IRCiSod, 2006), 288.

${ }^{2}$ Muhammad Shahrur, Nahwa Usul Jadi dalil Figh al-Islami: Figh al-Mar'ah, (Damaskus alAbali litTiba'ah,2000), 174.

${ }^{3}$ Ibid.,27.
} 
terikat baik ia antara manusia dengan Tuhan, manusia dengan manusia dan manusia dengan alam. Bukan hanya Sharur, para pemikir lain pun demikian, cuma pembacaan yang dilakukan oleh para pemikir seakan terpisah karena memang menurut mereka pembacaan yang tiga tersebut tidak terjadi secara integratif. Yang pada akhirnya menimbulkan bias tersendiri dan kedalaman tersendiri yang kadang tidaksaling bertegur sapa, bahkan terlihat tidak saling membutuhkan. Katakanlah, para tokoh pendiri fiqh klasik, kodifikasi dan kebijakan mereka dalam fiqh terlihat berdiri sendiri tidak menyeluruh dan berjalan secara linear. Tidak jarang ditemukan berbagai putusan hukum yang tidak sejalan dengan kemanusiaan dan sebagainya. Begitu juga dengan kebanyakan pakar dari Barat, yang mayoritas dari mereka meneliti kehidupan sosial dengan paradigma naturalistik. Metode tersebut telepas dari hubungannya dengan hal-hal yang suprarasional dan menegasikan Tuhan sehingga tidak memungkinkan ditemukan unsur nilai keilahiyahan dalam konsep dan kebijakan yang mereka bangun. Amat begitu berbeda dengan Sharur, justru yang ketiga hal tersebut, yaitu, ke-ilahiyah-an, kemanusiaan dan ke-alam-an menjadi satu metodologi untuk menghasilkan sebuah pembacaan baru yang dipandang relevan bagi manuisa saat ini.Ia bahkan menganalisis ayat-ayat mubkam menggunakan hukum matematika dan menganalisis ayat mutsyabih melalui pembacaan saintis.

Ketiga kondisi di atas (kondisi berada, kondisi berperosesdan kondisi menjadi, bila dihadapkan kepada realitas sosial umat Islam saat ini, menurut Sharur, kondisi umat Islam masih dalam tahapan kondisi berproses. Meskipun menurutnya sudah ada perobahan namun belum signifikan. Perobahan itu menurutnya adalah hasil dari meminjam alat-alat elaborasi (teori sosial) yang dimiliki oleh ilmuan di luar Islam. Dari sini muncullah kebijakan-kebijakan tentang perempuan atau kebijakan dalam masalah lain, misalnya kebijakan tentangburuh dan ekonomi. Walaupun demikian ia tidak menyalahkan peminjaman tersebut. Tetapi menurutnya, kondisi statis umat Islam dalam memahami wahyu, perlu digeser menjadi mind creatif dengan lahan pembacaan Al-Qur'an dan Sunnah yang menjadi pusaka dalam Islm. Dari sini telihat bahwa Sharur meyakini betul bahwa teks wahyu Salih li kulli makanin wa raman.Tetapi pembacaan ulang terhadap Al-Qur'an dan Sunnah yang ia maksud ialah tidak harus sama bahkan pendapat atau produk masa lalu harus disimpan dulu untuk menghasilkan hal yang genuin, bukan hanya sekedar syarah.

Muncul pertanyaan, kenapa para perempuan dalam Islam terlihat dianggap masih sebagai makhluk kedua atau setengah manusia? Banyak alasan yang dibeberkan oleh Sharur sehingga membentuk sebuah pusaran kesalahan, menurutnya problem awal yang menyandera kebebasan wanita melalui 
kebijakan-kebijakan yang disandarkan kepada Nas\} dalam Islam adalah genggaman dari histori politik perebutan kekuasaan yang merembet kepada penafsiran teks yang tidak adil bila dikaitkan dengan peranan kaum wanita. Lebih jelasnya akan di jelaskan pada tema-tema selanjutnya.

\section{Intraksi Kainunah, Sairurah dan Sairurah dengan Tanzilul Hakim}

Pembacaan ulang terhadap Al-Qur'an perlu dilakukan dengan pendekatan kontemporer Qirat al-Muairah). Pembacaan menurut Sharur ini adalah pembacaan dengan mencari dalil, merenungi, menemukan, memparkan dan menganalisis. Sementara makna dari al-Muas\}irabmenurutnya adalah untuk menekankan perlunya menjaga wacana epistemologi meskipun bersinggungan dengan warisan pemikiran dalam Islam. ${ }^{4}$ pembacaan kontemporer terhadap AlQur'an mengandaikan bahwa Al-Qur'an dapat dipahami dengan baik bagi masyarakat kontemporer jika dibaca dengan pembacaan kontemporer artinya dibaca sesuai masanya tidak harus kembali kepada pembacaan masa lalu. Sharur sampai pada kesimpulan:

Jika ulama us $\}$ ul fiqh telah menetapkan secara teoritis prinsip تغيرالأحكام بنغير الزمان (berubahnya hukum disebabkan berubahnya zaman) maka kita menetapkan secara teoritis dan praktis bahwa hukum dapat berubah juga dengan berubahnya sistem ilmu pengetahuan. ${ }^{5}$

Di dalam penjelasan lain juga, ia menekankan perubahan kebijakan fiqh secara revolusioner tanpa harus mengikuti kebijakan fiqh otoritatif Shafi'i, Maliki, Hanafi, Hanbali karena menurutnya kebijakan-kebijakan fiqh yang mereka telorkan disesuaikan dengan zaman dan tempatnya. ${ }^{6}$ Penulis memberi contoh, katakanlah Imam Shafi'i ketika mengeluarkan hukum-hukum batas air seteril dalam berwudu dari segi kuantitas dan kualitas, terlihat betul bahwa hukum yang imam Shafii keluarkan dipengaruhi oleh kondisi geografis dan waktu. Oleh sebab itu pula disebagian fatwanya ada yang ditukar setelah ia pindah tempat yang disebut dengan istilah Qaul Qadim dan Jadid.

Paparan di atas, terlihat bahwa Sharur mengajak untuk menukar fiqh yang ada saat ini dengan pembacaan realitas kekinian. Bukan kembali membangun fiqh berdasarkan struktur pemahaman fiqh klasik. Qur'an juga memberikan spirit itu, sebagai korpus terbuka Qur'an tidak berhenti untuk 
dijadikan sebagai pusat perhatian. Mengembangkan makna ayat dalam teks untuk membingkai kebijakan-kebijakan fiqh untuk saat ini.

Ketika konsep trilogi dihadapkan kepada at-Tanzil, Shahrur menjadikan at-Tanzil sebagai being (kainunah) dalam zatnya saja sebab at-Tanzil hadir dari sisi Tuhan yang bersifat being (kainunah)dalam zatnya. Oleh kerena itu at-Tanzil tidak akan bisa dipahami secara tuntas kecuali dari sisi alam eksistensi penciptanya, yakni Allah. Artinya tidak akan ada yang mampu menguasai dan memahami at-Tanzil secara utuh meskipun itu Nabi Muhammad sendiri. Manusia hanya mampu menguasainya pada level proses dan be comingnya (sairurah) sendiri. Yaitu, dibatasi oleh problema-problema yang harus dipecahkan oleh hukum-hukum ilmu pengetahuan yang dipergunakan oleh manusia dalam memecahkan masalah itu sendiri. ${ }^{8}$

Dari landasan filosfis di atas, Shahrur mencoba pembacaan baru dari terhadap at-Tanzil dengan membagi ayat dalam kategorikenabian dan kerasulan. Ayat dalam kategori kenabian terdapat pada ayatmutasyabih dan ayat la mubkam wa la mutasyabih. Ayat mutasyabih jugaterbagi menjadi dua; Al-Qur'an al-Adzim dan Sab'ul Matsani. Dari sisikandungannya berisi tentang ayat informasi baik tentang akidah, kisah, dan pengetahuan ilmiah sehingga tidak dapat diubah dan berada di luar lingkup ikhtiar manusia yang kemudian disebut dengan qadar. Sedangkan ayat yang masuk kategori kerasulan merupakan kumpulan yang berisi pengetahuan pengetahuan objektif yang berada di luar kesadaran manusia, yang berfungsi untuk menjelaskan hakikat wujud objektif tanpa subjektifitas manusia dan membedakan antara hak dan batil seperti informasi kematian, hari kiamat, kebangkitan, surga dan neraka. ${ }^{9}$

\section{Intraksi Kainunah, Sairurah dan Sairurah dengan Sunnah Nabi}

Tidak dapat dipungkiri bahwa adanya dekonstruksi syariah telah menyentuh pada rekonsepsi sunnah. Hal itu terlihat jelas dari beberapapernyataan tokoh dalam melihat kembali pemahaman sunnah.Sebut saja Fazlurrahman yang menyatakan bahwa sunnah pada hakekatnya merupakan konsep yang tidak memiliki kandungan spesifik bersifat mutlak. Hal inilah yang ditinggalkan oleh muslim sekarang. Sehingga produk-produk pemikiran sekarang tidak sekreatif dan sefleksibel dahulu dalam merespon perubahan dan

${ }^{7}$ Komaruddin Hidayat, Memahami Babasa Agama: Sebuah Kajian Hermeneutik (Jakarta: Paramadina,1996), 15.

$\left.{ }^{8} \mathrm{Nah}\right\}$ wa Usul Jadi dab lil Fiqh al-Islami...54-55.

${ }^{9}$ Muhammad Shahrur, al-Kitab Wa Al-Qur'an; Qira'ab Mu'ashirah, (Damaskus ; al-Ahali li at-Taba'ah Wa al-Nasr Wa al-Tauzi'1992), 55. 
perkembangan yang terjadi. ${ }^{10} \mathrm{Hal}$ yang sama diutarakan oleh Arkoun dan 'Abdullah Ahmad al-Na'im yang menolak kesakralan teks-teks keagaman termasuk sunnah. ${ }^{11}$ Hingga kini upaya tersebut masih dilakukan.

Secara terminologis, Sahrur mengistilahkan sunnah dengan tiga kriteria pokok. Pertama, sunnah Nabi hanyalah bentuk ijtihad Nabi dalam menerapkan hukum tanpa keluar dari batas yang ditetapkan oleh Allah di dalam umm al-Kitab dan sangat terikat dengan sifat lokal-temporal. ${ }^{12}$ Kedua, sunnah tidak bersifat mutlak dan tidak harus diterapkan di semua zaman. ${ }^{13}$ Ketiga sunnah sebagai usaha Nabi SAW dalam menerapkan hukum-hukum Allah agar bisa dipraktekkan di zamannya menunjukkan bahwa kita juga bisa dan lebih berhak menghasilkan "sunnah" yang cocok untuk kondisi kekinian.

Berdasarkan pengertian di atas, kita dapat menyimpulkan kecenderungan Shahrur dalam memandang Sunnah. Yang paling mencolok adalah Shahrur melihatsunnah sebagai bentukan realitas. Dalam artian sunnah hanyalah respon Nabi Muhammad atas realitas ketika itu dalam rangka menerapkan hukumhukum Allah agar bisa dipraktekkan dengan mudah. Secara teori dapat diungkapkan, dengan pengertian di atas Shahrur ingin meyakinkan bahwa setiap realitas akan membentuk pemahaman baru dan sunnah yang baru.Hal ini juga dibuktikan dari optimismeShahrur bahwa kita di zaman ini bisa membentuk sunnah berangkat dari perangkat keilmuan yang dimiliki. Beberapa fakta di atas memperlihatkan bahwa Sunnah dipandang sebagai ijtihadnya Rasulullah dan sehingga statusnya tidak lebih dari hanya ijtihad Rasulullah itu sendiri yang sudah pasti terikat oleh lokal dan temporal.

Interaksi trilogi Shahrur ketika dihadapkan kepada Sunnah, menurutnya, Sunnah adalah cerminan awal dari at-Tanzil sebagai sesuatu yang memiliki kondisi berada dalam dirinya (penafsir awal). Namun tetap berada pada lingkup tertentu, sejarah tertentu dan masyarakat tertentu yang berada pada alam realitas objektif manusia. Dari sini, ucap Shahrur, Rasulullah bukanlah filosof juga bukan pemikir. Melainkan seorang Da'i yang mendapatkan ide wahyu dari zat yang absolut (Allah SWT). Sharur juga menentang keras penyatuan level atTanzil dengan Sunnah sebagaimana yang telah dilakukan oleh kaum konservatif

${ }^{10}$ Fazlur Rahman, Membuka Pintu Ijtihad, terj. Ana Mahyuddin. (Bandung, Pustaka, 1995), 16

${ }^{11}$ Amin Abdullah, "Arkoun dan Kritik Nalar Islam", dalam Tradisi, Kemodernan dan Metamodernisme: Memperbincangkan Pemikiran Mohammed Arkoun. (Yogyakarta: LKiS,1996), 7.

12 Muhyar Fanani, "Fikih Madani, Kontruksi Hukum Islam di Dunia Modern."Cet. I, (LKis,Yogyakarta,210), 201-202.

${ }^{13}$ Muhammad Shahrur, Al-Kitab wa Al-Qur'an; Qira'ab Mu'as\}irah, (Damaskus: Al-Ahali, 1990). 549. 
saat ini. Menurutnya Sunnah itu kondisi keberadaannya ada dalam diri Nabi yang diaktualkan dalam kondisi berproses dan menjadi. ${ }^{14}$

\section{Pengaruh Hegelian}

Pemikiran Shahrur, juga banyak dipengaruhi oleh dialektika Hegel. Meski hipotesis ini tidak dinyatakan oleh Shahrur secara transparan dalam setiap tulisannya. Namun hal ini bisa dilihat dari argumen-argumen yang menaungi pemikirannya. Lebih jelas diungkap oleh Muhammad Thahir ketika memberi kritik terhadap pemikiran Shahrur. Menurut hasil identifikasinya, Shahrur di ilhami oleh ide Hegel tentang pandangannya memahami alam dan manusia. Di antaranya, (1) pandangan mengenai peristiwa-peristiwa alam yang bersifat dialektik, dalam arti, bahwa untuk menyingkapi berbagai kontradiksi yang terdapat dalam pemikiran dan opini diperlukan pengujian yakni pengeujian dialektika; (2) alam manusia dan kehidupan dipandang sebagai materi yang berkembang. ${ }^{15}$

Realitas alam menurut Shahrur merupakan premis-premis dialektis yang yang bersifat materil dan selalu berubah. Sementara adanya realitas yang kontradiktifdan berpasangan mengantarkan pada suatu bentuk kesimpulan bahwa setiap alam (segala sesuatu selain diciptakan) mengimplikasikan kehebatan Tuhan yang lebih maha dari segalanya. Upaya pembongkaran secara besar-besaran terhadap seluruh pemikiran Islam. Kemudian dilanjutkan dengan pendekatan dan metodologi baru menunjukkan bahwa Shahrur juga menggunakan metode dekonstruksi. Hal ini dipicu oleh kegelisahan Shahrur melihat pemikiran keislaman yang hanya berkutat pada ideologi semata, baik ia kalam maupun mazhab. ${ }^{16}$

\section{Pendekatan Sharur}

Sudah tidak terbentahkan lagi bahwa dalam mengelaborasi dan pemaknaan ulang yang kandungan Al-Qur'an, tentu menggunakan pendekatan bahasa/linguistik. Fisafat bahasa Shahrur dipengaruhi oleh Ja'far Dakk al-Bab yang merupakan teman sejawatnya sekaligus gurunya di bidang ilmu linguistik. Pendekatan bahasa yang digunakan oleh Shahrur adalah pendekatan historis ilmiah dalam studi bahasa yang di dasarkan pada teori linguistiknya Abu Ali Al-

${ }^{14}$ Nah $\}$ wa Usul Jadi dah lil Figh al-Islami...101-103.

${ }^{15}$ Mahami Munir Muhammad T\}ahirash-Shawwaf, Tahafut al-Qira'ah al-Mu'as\}irah, (Cyprus: Ash-Shawwf li an-Nashr wa ad-Dirasat,1993), 31.

16 Muhammad Shahrur, Al-Kitab wa Al-Qur'an: Qira'ah Mu'as\}irah, Cet.II, (Damaskus: al-Ahaliy li at-Thiba'ah wa an-Nasyr wa at-Tawzi', 1990),46-47. 
Farisi di mana di dalamnya mencakup teori linguistiknya Ibn al-Jinni dan Abdul Qadir al-Jurjani. ${ }^{17}$

Dari Ibn Jinni, Shahrur menggunakan teori linguistiknya yang terangkum dalam postulat-postulat sebagai berikut: pertama, adanya struktur bahasa atau kalimat termasuk suara sebagai sumber bahasa, kedua, bahasa tidak tercipta dalam suatu waktu melainkan berkembang secara evolutif, ketiga, bahasa senantiasa mengikuti sistematika atau aturan strukturnya, dan keempat, adanya pertautan antar bahasa, suara dan psikologis penggunanya. ${ }^{18}$ Sedangkan alJurjanidia mengambil dua teori dasarnya, yaitu, pertama, tenetang struktur bahasa dan fungsi transmisinya dan kedua, adandya keterkaitan bahasa dan pemikiran. ${ }^{19}$

Penggabungan dari dua teori tersebut menghasilkan formulasi linguistik yang terangkum dalam tiga postulat, yaitu, pertama, bahwa bahasa memiliki struktur, kedua, bahasa merupakan penampakan fenomena sosial, dan ketiga, adanya relasi antara bahasa dan pemikiran. formulasi tersebut ternyata belum cukup bagi Shahrur untuk menopang kekurangan itu ia menggunakan Mu'jam Maqayis al-Farisy, dari sini Shahrur menemukan asumsi dasarnya bahwa dalam bahasa Arab tidak ditemukan sinonimitas. ${ }^{20}$

Kemudian dari gabungan itu semua, Shahrur merumuskan kaedahkaedah dasar metodologi linguistiknya, sebagai berikut,

1. Dalam bahasa Arab tidak ada sinonimitas, yang ada justru sebaliknya satu kata bisa memiliki makna yang banyak.

2. Kata adalah ekspresi dari makna.

3. Inti dari bahasa arab adalah maknanya.

4. Bahasa apapun tidak akan dapat dipahami jika tidak ditemukan adanya kesesuaian bahasa itu dengan rasio dan relaitas objektif. ${ }^{21}$

Dengan di dasarkan pada teori bahwa kata adalah ekspresi makna dan yang terpenting dari satu bahasa adalah maknanya, maka Shahrur menggunakan pendekatan semantik dengan analisis paradigmatis dan sintagmatis. ${ }^{22}$ Semantik adalah ilmu yang berhubungan dengan fenomena makna dari pengertian yang

${ }^{17}$ Ibid., 20.

${ }^{18}$ Ibid., 21.

${ }^{19}$ Ibid., 20.

${ }^{20} \mathrm{Ibid}, 22$.

${ }^{21}$ Ibid,. 44.

${ }^{22}$ Sahiron Syamsuddin, Metode Intertekstualitas Muhammad Shabrur dalam Penafsiran AlQur'an, dalam Abdul Mustaqim dan Sahiron Syamsuddin(eds.) Studi Al-Qur'an Kontemporer Wacana Baru Berbagai Metodologi Tafsir, (Yogyakarta: Tiara Wacana, 2002),131. 
paling luas dari sebuah kata. Sehingga hampir apa yang mungkin dianggap mempunyai makna dapat dianggap sebagai obyek semantik. Makna dalam penegertian ini dilengkapi persoalan-persoalan penting dari pemikir yang datang dari berbagai latar belakang keilmuan, seperti, sosiologi antropologi, psikologi, matematika, dan lain-lain. Di samping itu sebagai studi makna semantik senantiasa berkembang sesuai dengan sesuai dengan minat dan latar belakang keilmuannya. ${ }^{23}$ Analisa paradigmatis yang dimasksud adalah suatu analisa pencarian dan pemahaman terhadap sebuah konsep (makna) suatu simbol (kata) dengan cara mengaitkannya dari konsep-konsep simbol lain yang mendekati dan berlawanan. Sedangkan analisa sintagmatis adalah analisa yang bertujuan menetapkan makna yang paling tepat di antara makna-makna yang ada, dimana setiap kata pasti dipengaruhi hubungannya secara linear dengan kata-kata di sekelilingnya. ${ }^{24}$

\section{Teori Hudud (limit)}

Pada dasarnya konsep pewahyuan sebagaimana dipahami oleh Sharur tidak berbeda dengan para pemikir lainnya. Namun pendekatan bahasa dan logika yang ia gunakan berhasil memberikan konstribsi dalam dua tahap pewahyuna tersebut. analisis kebahasaan Shahrur terhadap kata al-Inzal dan atTanzil dalam konteks pewahyuan Al-Qur'an telah menghasilkan kesimpulan bahwa kata al-Inzal berarti merubah sesuatu yang tidak mungkin ditangkap oleh manusia (غدرك) أمدركة) menjadi sesuatu yang dapat dicerna (مدرك) Dari sinilah Shahrur membagi-bagi dan mengelompokkan setiap ayat yang disesuaikan penamaan dan pengolompakannya bahkan sangat terkait kepada pembagian Al-Qur'an itu sendiri.

Teori hudud ini diilhami oleh oleh dua aspek yang tidak dibaca secara serius oleh pemikir lain seperti Shahrur memhaminya. Yaitu, al-istiqamah dan albanifiyyah. Shahrur menggunakan pengamatan dan pendalaman menggunakan analisis linguistik terhadap dua akar kata tersebut, sehingga dari pengamatan panjang itu ia menemukan dua kata kunci yang menjadi landasan normatif teori budud yang ia gagas, yaitu, al-hanifyah sebagai fitrah manusia dan al-istiqamah sebagai batasan ruang gerak dinamika manusia dalam menentukan hukum. ${ }^{25}$

Sebagaimana penejelasan sebelumnya, termasuk salah satu dari pembagaian Al-Qur'an adalah munculnya penyebutan Umm al-Kitab yaitu pembagian nama dari pengelompokan ayat-ayat budud. Ayat ini adalah ayat yang

${ }^{23}$ Toshihiko Izutsu, God and Man in The Koran: Semantics of Koranic Weltanschanung (New Hampshire USA: Ayer Company Publisher Inc.: 1987), 10-11.

${ }^{24}$ Ibid 139

${ }^{25}$ Al-Kitab wa Al-Qur'an: Qira'ah Mu'asirah... 449. 
menerangkan tentang batasan dari ketentuan hukum Allah yang berisi tentang ibadah, wasiat kebaikan, ajaran-ajaran secara umum dan ayat-ayat yang bersifat kondisional. Dalam konteks fungsi legislasi, ayat budud ini memiliki posisi yang sangat penting karena di dalam ayat-ayat inilah terkandung asas legislasi hukum Islam. Lebih jelasnya hasil ijtihad harus berada pada batasan-batasan yang telah ditentukan dalam ayat-ayat tersebut. ${ }^{26}$

Hasil dari semua cara kerja Sharur melahirkan sebuah teori aflikatif yakni nazhriyyah al-budud. Teori batasnya terdiri dari batas bawah (al-hadd aladna/minimal) dan batas atas (al-hadd al-a'la/maksimal). Terdapat enam bentuk aplikatif teori batas ini dalam kajian terhadap ayat-ayat hukum, yakni:

1. Hanya memiliki batas bawah. Hal ini berlaku pada perempuan yang boleh dinikahi (QS.[4]: 22-23), jenis makanan yang diharamkan (QS. [5]: 3), [6]: 145-156), hutang piutang (QS. [2]: 283-284), dan pakaian wanita (QS. [4]: $31)$.

2. Hanya memiliki batas atas. Berlaku pada tindak pidana pencurian (QS. [5]: 38) dan pembunuhan (QS. [17]: 33, [2]: 178, [4]: 92).

3. Memiliki batas atas dan bawah sekaligus. Berlaku pada hukum waris (QS. [4]: 11-14, 176) dan poligami (QS. [4]: 3).

4. Ketentuan batas bawah dan atas berada pada satu titik atau tidak ada alternatif lain dan tidak boleh kurang atau lebih. Berlaku pada hukum zina dengan seratus kali cambuk (QS. [24]: 2).

5. Ketentuan yang memiliki batas bawah dan atas sekaligus, tetapi keduanya tidak boleh disentuh, jika menyentuhnya berarti telah melanggar aturan Tuhan. Berlaku pada hubungan laki-laki dan perempuan. Jika antara laki-laki dan perempuan melakukan perbuatan mendekati zina tetapi belum berzina, maka keduanya belum terjatuh pada batas-batas hudud Allah.

6. Memiliki batas atas dan bawah, di mana batas atasnya bernilai positif dan tidak boleh dilampaui. Sedang batas bawahnya bernilai negatif dan boleh dilampaui. Berlaku pada hubungan kebendaan sesama manusia. Batas atas yang bernilai positif berupa riba, sementara batas bawahnya bernilai negatif berupa zakat. ${ }^{27}$ 


\section{Penutup}

Hak perempuan merupakan bagian dari HAM sangat urgen untuk ditopang oleh kebijakan-kebijakan teologis. Apalagi jika melihat realitas saat ini yang terjadi di belahan dunia, di sana-sini, masih banyak yang menganggap perempuan bukanlah manusia merdeka. Penindasan fisik dan hak bahkan tidak diterimanya kaum hawa di ruang publik Islam menjadi momok yang tidak mendapat perhatian dari kalangan penggagas fiqh masa lalu. sehingga menciptakan ketimpangan yang berdampak pada sistem sosial.

Upaya Shahrur memang tergolong begitu radikal dalam membongkar pemahaman fiqh wanita. Proyek yang ia lakukan semata-mata untuk menyetarakan hak wanita dan untuk mengembalikan hak asli yang tidak terkontaminasi dengan kepentingan dan penetrasi politik masa lalu. Tanpa adanya pembongkaran secara radikal ini menurutnya Islam tidak akan mampu menyentuh jantung peradaban. Sebagaimana diketahui dalam penjelasannya, Hukum Tuhan memliki batas-batas ketundukan kepada fitrah manusia dengan seiring perkembangan nilai-nilai standar etika yang mulia. Dengan dekonstruksi epistemologi fiqh yang ia gagas terlihat memberi ruang yang begitu luas untuk perempuan agar mampu bisa mewujudkan cita-citanya sebagai perempuan. 
145 | Al-Istinbath: Jurnal Hukum Islam, Vol.3, No.2, 2018

\section{Daftar Pustaka}

Abdullah,Amin, "Arkoun dan Kritik Nalar Islam", dalam Tradisi, Kemodernan dan Metamodernisme: Memperbincangkan Pemikiran Mohammed Arkoun. Yogyakarta: LKiS,1996.

ash-Shawwaf,Mahami Munir Muhammad Tahir,Tahafut al-Qira'ah alMu'asirah,Cyprus: Ash-Shawwf li an-Nashr wa ad-Dirasat,1993.

Fanani,Muhyar, "Fikih Madani, Kontruksi Hukum Islam di Dunia Modern." Cet. I, LKis,Yogyakarta,210.

Hidayat,Komaruddin,Memahami Bahasa Agama: Sebuah Kajian Hermeneutik Jakarta, Paramadina,1996.

Izutsu,Toshihiko,God and Man in The Koran: Semantics of Koranic Weltanschaung, New Hampshire USA: Ayer Company Publisher Inc.: 1987.

Rahman,Fazlur,Membuka Pintu Ijtihad, terj. Ana Mahyuddin. Bandung, Pustaka, 1995.

Shahrur, Muhammad, Al-Kitab wa Al-Qur'an: Qira'ah Mu'asirah, Cet.II, Damaskus: al-Ahaliy li at-Thiba'ah wa an-Nasyr wa at-Tawzi', 1990.

-----Muhammad, Nahwa Usul Jadi dablil Figh al-Islami: Figh al-Mar'ah, Damaskus al-Ahali litTiba'ah,2000.

Shofan, Moh,Jalan Ketiga Pemikiran Islam, Cet. I. Jogjakarta: IRCiSod, 2006.

Syamsuddin,Sahiron,Metode Intertekstualitas Muhammad Shahru $>r$ dalam Penafsiran Al-Qur'an, dalam Abdul Mustaqim dan Sahiron Syamsuddin(eds.) Studi Al-Qur'an Kontemporer Wacana Baru Berbagai Metodologi Tafsir, Yogyakarta: Tiara Wacana, 2002. 
Suheri Saputra Rangkuti: Dekonstruksi Epistemologi Muhammad Shahrur | 146 